\title{
Yield Gap and Factor Influencing Yield Gap in Sugarcane Cultivation in Ahmednagar District of Maharashtra
}

\author{
G. M. Bodakhe, S. S. More and N. R. Dhokar* \\ Department of Agricultural Economics, College of Agriculture, Latur, India \\ *Corresponding author
}

\section{A B S T R A C T}

\begin{tabular}{l} 
K e y w o r d s \\
$\begin{array}{l}\text { Sugarcane, } \\
\text { Potential yields, } \\
\text { Potential farm } \\
\text { yields, Actual yields } \\
\text { Yield gap and factor } \\
\text { affecting yield gap }\end{array}$ \\
\hline Article Info \\
\hline $\begin{array}{l}\text { Accepted: } \\
\text { 12 November } 2020 \\
\text { Available Online: } \\
\text { 10 December } 2020\end{array}$ \\
\hline
\end{tabular}

Sugar cane (Saccharum officinarum L.), the tall perennial grass from the family member of the grass family Gramineae, is the major sugar crop from which sugar is produced. Study on yield gap of sugarcane was conducted in Ahmednagar district of Maharashtra. This paper is an attempt the yield gaps analysis in different planting types of sugarcane in Ahmednagar of Maharashtra. The actual yields obtained are considerable lower than those recorded in the demonstration plots and research stations/farms. Therefore, there is need to know the different yield gaps between farmer's fields and the demonstration plots. In the present study, an attempt has been made to analysis the yield gap and constraints faced in the adoption of sugarcane production by the farmers of Maharashtra. Results reveal that the magnitude of yield gap-I was higher, which implies that, the technology developed at research station cannot be duplicated on demonstration plots to exploit the full potential of sugarcane. This gap was attributable to environmental differences and non-transferable component of technology. The orthodox practices being followed on farmer's field lead to yield gap-II. The farmers usually do not adopt a technology as a package but take up individual practices suitably trimmed to fit into their budget and skills (management and operational) which lead to the variation in the adoption of cultural practices and consequently to the yield gaps. The yield gaps cannot be completely eliminated, but can be minimized by efficient and effective resources management

\section{Introduction}

Sugarcane is one of the most important commercial crops in Maharashtra grown over an extent of 9.02 lakh ha. Maharashtra is the highest sugar producing state of India. Maharashtra sugarcane yield in 2017-18 was 80.10 tonnes /ha, much higher compared to the yield of 59.58 tonnes/ha for the second highest sugar producing state Uttar Pradesh and national average of 70.31 tonnes/ha. The average sugar recovery rate of the four sugarcane cultivation types in Maharashtra was 11.32 per cent in 2017-18; the recovery rate of Adsali sugarcane was even higher at 12.3 per cent. The average recovery percentage of Maharashtra was way above the recovery percentage of Uttar Pradesh at 9.16 per cent and all India percentage of 10.25 per cent. In terms of the land productivity adjusted for recovery rate is even higher for Maharashtra at 98.8 tonnes/ha (161.14 
tonnes/ha for Adsali) compared to 61.04 tonnes/ha for Uttar Pradesh.

The four types of sugarcane cultivation prevalent in Maharashtra, ratoon is most popular with 40 per cent cane area under it, possibly since it has shortest duration of 11 months, fitting almost perfectly with the annual October to March cane crushing season. Same can be said about Suru type, which is having duration of 12 months and coverage of 20 per cent. Adsali type has the highest yield and recovery rate, but has only 10 per cent of the sugarcane area is under cultivation, possibly due to the longest duration of 17 months. Pre-seasonal type, as the name suggests, is planted about 2.5 months before the season, and stands between ratoon and Adsali in terms of duration, yield and recovery rate.

\section{Materials and Methods}

Study Area: The study was conducted in Ahmednagar district of Maharashtra Keeping in mind the objectives of the study, multi stage stratified random sampling technique was used. The list of sugarcane growers from the selected village were obtained from the revenue records maintained at selected villages and then categorized into four groups according to planting types of sugarcane. Five farmers from each type i. e. Adsali, Suru, Preseasonal and Ratoon sugarcane were selected separately from each village from both the tahsils by simple random sampling technique. Thus, 20 farmers were selected from each village. In all 120 sugarcane growers comprising 30 farmers from each planting type of sugarcane were selected separately for the present study.

Data and its sources: The primary data was collected from sample sugarcane growers by the survey method. The sample sugarcane growers were contacted individually for collection of required information. The information on research station yields and yields of field level demonstration plot were obtained from the Central Research Station Padegaon (M. S.) The data were collected for the crop harvested in the year 2017-18. The plantation type wise viz., Suru, Pre-seasonal, Adsali and Ratoon use levels of various inputs and outputs obtained in sugarcane cultivation and the yield gap were estimated by simple tabular method with the help of means, averages and percentages, etc., by keeping in view the objectives of study.

\section{Yield gap}

Potential yields: The available data from several breeders' trials was collected from the recently published reports of the All India Coordinated Improvement Projects of the on sugarcane crop.

Potential farm yields: The on-farms yields were obtained from the frontline demonstrations data, available for sugarcane the recent years. Taken from the Central Research Station Padegaon (M. S.)

Actual yields: The data was collected from sample sugarcane growers by the survey method on the farm.

Factor affecting yield gap: The empirical evidences from the previous studies suggested that, the multiple linear regression equation has been used in agriculture for studying the relationship between yield gap and input variables.

\section{Results and Discussion}

\section{Yield gaps}

The concept of yield gaps in crops originated from different constraint studies carried out by International Rice Research Institute 
(IRRI) during the seventies. The yield gap comprises at least two components. The first component-yield gap I is the difference between experiment/research station yield (potential yield) and the potential farm yield.

The first of these cannot be narrowed, is not exploitable, and mainly owes to factors that are generally not transferable, such as the environmental conditions and some of the built-in technologies that are available at research stations or experimental farms. It is hypothesized that yield differences exist between the levels obtained at experimental or research station and the potential of the same varieties on farmers fields (Fig. 1).

The second component- yield gap II is the difference between the potential farm yield and the actual average farm yield and provided a similar description of the yield gaps and components. The second component arises when farmer deviates from the recommendation to achieve the agronomic yield potential.

This yield gap II is exploitable and is the focus of the study. A large yield gap II implies that farmers did not fully adopt the existing technologies because they were not packaged appropriately or because economic conditions made them unattractive. A small yield gap, on the other hand, indicates that the available technologies are almost fully used. The yield gap reflects mainly differences in management practices (for example, the amount of fertilizer used, land preparation, time of the year of different practices) under similar agro ecological conditions.

For example, the national average yield is not an appropriate indicator of farm-level performance because it is an average across different agro climatic zones, different soil types, different crop ecologies, crop types, and technologies. For this reason, it is important to obtain average yields from homogenous agro ecological conditions, similar to those used to measure potential yields, and also under similar production systems (technologies).

The two yield gaps have been calculated on the basis of per hectare potential yield, potential farm yield and actual yield obtained. It may not possible for all farmers to raise the crop productivity on their farms to the level of research station. However, it would be realistic to aim at demonstration plot yield (potential farm yield) level. Therefore, emphasis was given on yield gap-II and here in after simply referred as yield gap. In all, three types of yield gaps viz., Yield gap-I [Potential yield (Yp) - Demonstration plot yield (Yd)], Yield gap -II [Demonstration plot yield (Yd) - Actual yield (Ya)] and Yield gap -III or total yield gap [Potential yield (Yp) Actual yield (Ya)] has been estimated on per hectare basis for different planting types of sugarcane.

\section{Adsali sugarcane}

In Adsali sugarcane cultivation yield realised on the research station (200 tonnes per hectare) and on demonstration plots (160 tonnes per hectare) were significantly higher than yield on sample farms (130.00 tonnes per hectare). It is inferred that there is 20.00 per cent of yield gap between potential yield realised at research station and the yield that was reported at the demonstration plots. This gap is nothing but yield gap I, which explains the extent of the untapped potential yield that is possible to achieve at the sample farms. Yield gap II which is the difference between the potential farm yield $(\mathrm{Yd})$ and the actual yield (Ya) was 18.75 per cent. The total yield gap which indicates the difference between potential yield (Yp) and actual yield (Yp) was 35.00 per cent. 


\section{Pre-seasonal sugarcane}

The potential yield at research station was 164 tonnes per hectare while potential farm yield at demonstration plots was 130 tonnes per hectare. The actual yield of sample farms was 115.00 tonnes per hectare. The yield gap I for preseasonal sugarcane was 20.73 per cent and yield gap II was 13.84 per cent. The total yield gap III was observed at 31.70 per cent at overall level. Among the size farms maximum yield gap I, yield gap II and yield gap III were noticed in range of 24 to 44 per cent.

Table.1 Yield gap in sugarcane cultivation ( $\mathrm{t} / \mathrm{ha})$

\begin{tabular}{|c|c|c|c|c|c|c|}
\hline \multirow{2}{*}{$\begin{array}{l}\text { Sr. } \\
\text { No }\end{array}$} & \multirow{2}{*}{$\begin{array}{c}\text { Particulars } \\
\text { tonnes }\end{array}$} & \multicolumn{4}{|c|}{ Planting types } & \multirow[b]{2}{*}{ Overall } \\
\hline & & Adsali & Pre-seasonal & Suru & Ratoon & \\
\hline 1 & Potential yield & 200 & 164 & 150 & 125 & 159.50 \\
\hline 2 & Potential farm yield & 160 & 130 & 115 & 110 & 128.75 \\
\hline 3 & Actual yield & 130 & 112 & 90 & 72 & 101.25 \\
\hline 4 & Yield Gap - I $\left(\mathbf{Y}_{\mathbf{p}}-\mathbf{Y}_{\mathbf{d}}\right)$ & 40 & 34 & 35 & 15 & 31 \\
\hline 5 & Yield Gap - II $\left(\mathbf{Y}_{\mathbf{d}}-\mathbf{Y}_{\mathbf{a}}\right)$ & 30 & 18 & 25 & 38 & 27.75 \\
\hline 6 & Yield Gap - III $\left(\mathbf{Y}_{\mathbf{p}}-\mathbf{Y}_{\mathbf{a}}\right)$ & 70 & 52 & 60 & 53 & 58.52 \\
\hline 7 & Percent yield gap-I & 20.00 & 20.73 & 23.33 & 12.00 & 19.01 \\
\hline 8 & Percent yield gap-II & 18.75 & 13.84 & 21.73 & 34.54 & 22.26 \\
\hline 9 & Percent yield gap-III & 35.00 & 31.70 & 40.00 & 42.40 & 37.77 \\
\hline
\end{tabular}

Table.2 Association between yield and related factor of production in sugarcane cultivation in study area

\begin{tabular}{|c|c|c|c|c|c|}
\hline \multirow{2}{*}{\multicolumn{2}{|c|}{ Particulars }} & \multicolumn{4}{|c|}{ Planting type } \\
\hline & & \begin{tabular}{|l} 
Adsali \\
sugarcane
\end{tabular} & $\begin{array}{l}\text { Pre-seasonal } \\
\text { sugarcane }\end{array}$ & $\begin{array}{l}\text { Suru } \\
\text { sugarcane }\end{array}$ & $\begin{array}{l}\text { Ratoon } \\
\text { sugarcane }\end{array}$ \\
\hline \multicolumn{6}{|l|}{ Yield (y) } \\
\hline \multicolumn{2}{|l|}{ Farm size $\left(\mathrm{X}_{1}\right)$} & $0.998^{* * *}$ & $0.999^{* *}$ & $0.997^{* *}$ & $0.981^{* *}$ \\
\hline \multicolumn{2}{|c|}{ Number of set $\left(X_{2}\right)$} & $0.995^{* *}$ & $0.997^{* *}$ & $0.975^{* *}$ & - \\
\hline \multicolumn{2}{|c|}{ Expenditure on land prepration $\left(\mathrm{X}_{3}\right)$} & $0.993^{* *}$ & $0.994^{* *}$ & $0.989^{* *}$ & - \\
\hline \multicolumn{2}{|c|}{ Manures (qt.) $\left(\mathrm{X}_{4}\right)$} & $0.994^{* *}$ & $0.996^{* *}$ & $0.971^{* *}$ & $0.915^{* *}$ \\
\hline \multicolumn{2}{|c|}{ Number of Irrigations $\left(\mathrm{X}_{5}\right)$} & -0.331 & 0.200 & 0.207 & 0.026 \\
\hline \multicolumn{2}{|c|}{ Total Labour day $\left(\mathrm{X}_{6}\right)$} & $0.946^{* *}$ & $0.998^{* *}$ & $0.996^{* *}$ & $0.966^{* *}$ \\
\hline \multicolumn{2}{|c|}{ Machine power (hrs) $\left(\mathrm{X}_{7}\right)$} & $0.985^{* *}$ & $0.936^{* *}$ & $0.828^{* *}$ & $0.913^{* *}$ \\
\hline \multicolumn{2}{|c|}{ Age $\left(\mathrm{X}_{8}\right)$} & 0.284 & -0.133 & 0.154 & -0.112 \\
\hline \multicolumn{2}{|l|}{ Experience $\left(\mathrm{X}_{9}\right)$} & 0.245 & -0.056 & 0.200 & -0.047 \\
\hline \multicolumn{2}{|c|}{$\begin{array}{l}\text { Expenditure on } \\
\text { plant protection } \\
\left(\mathrm{X}_{10}\right)\end{array}$} & -0.161 & 0.289 & 0.231 & -0.116 \\
\hline \multicolumn{2}{|c|}{ Total value of asset $\left(\mathrm{X}_{11}\right)$} & $0.383^{*}$ & $0.657^{* *}$ & 0.013 & $0.559^{* *}$ \\
\hline \multirow[t]{3}{*}{ Fertilizer (kg.) } & $\mathrm{N}\left(\mathrm{X}_{12}\right)$ & $0.992^{* *}$ & $0.998^{* *}$ & $0.981^{* *}$ & $0.978^{* *}$ \\
\hline & $\mathrm{P}\left(\mathrm{X}_{13}\right)$ & $0.991^{* *}$ & $0.998^{* *}$ & $0.996^{* *}$ & $0.976^{* *}$ \\
\hline & $\mathrm{K}\left(\mathrm{X}_{14}\right)$ & $0.998^{* *}$ & $0.998^{* *}$ & $0.996^{* *}$ & $0.965^{* *}$ \\
\hline
\end{tabular}


Table.3 Results of estimated regression analysis of sugarcane on sample farms

\begin{tabular}{|l|c|c|c|c|c|}
\hline Particulars & $\begin{array}{c}\text { Unite } \\
\text { use }\end{array}$ & bi & S.E & $\begin{array}{c}\text { 't' } \\
\text { value }\end{array}$ & $\begin{array}{c}\text { 't' } \\
\text { prob }\end{array}$ \\
\hline Constant & - & -13.19 & 9.13 & -1.44 & 0.152 \\
\hline Number of set $\left(\mathrm{X}_{1}\right)$ & Thousand & $0.02^{* *}$ & 0.01 & 2.17 & 0.032 \\
\hline $\begin{array}{l}\text { Expenditure on } \\
\text { preparation }\left(\mathrm{X}_{2}\right)\end{array}$ & Rs & $0.02^{* *}$ & 0.01 & 2.61 & 0.010 \\
\hline Manures $\left(\mathrm{X}_{3}\right)$ & Quintls & 0.026 & 0.032 & 0.83 & 0.407 \\
\hline Fertilizer $\left(\mathrm{X}_{4}\right)$ & Kilogram & $0.210^{* *}$ & 0.04 & 5.14 & 0.00 \\
\hline $\begin{array}{l}\text { Number } \\
\text { Irrigations }\left(\mathrm{X}_{5}\right)\end{array}$ & Numbers & 0.92 & 0.60 & -1.51 & 0.133 \\
\hline Total labour $\left(\mathrm{X}_{6}\right)$ & Days & $0.07^{* *}$ & 0.02 & 3.82 & 0.001 \\
\hline Machine power $\left(\mathrm{X}_{7}\right)$ & Hours & $0.16^{* *}$ & 0.04 & -3.44 & 0.001 \\
\hline Age $\left(\mathrm{X}_{8}\right)$ & Years & 0.21 & 0.13 & 1.67 & 0.096 \\
\hline Experience $\left(\mathrm{X}_{9}\right)$ & Years & -0.19 & 0.13 & -1.46 & 0.146 \\
\hline $\begin{array}{l}\text { Expenditure on plant } \\
\text { protection }\left(\mathrm{X}_{10}\right)\end{array}$ & Rs & -0.002 & 0.002 & -1.45 & 0.149 \\
\hline Total value of assets $\left(\mathrm{X}_{11}\right)$ & Rs & -1.921 & 0.000 & -0.132 & 0.895 \\
\hline
\end{tabular}

$\mathrm{R}^{2}=0.869, \quad$ Adjusted $\mathrm{R}^{2}=0.884, \quad \mathrm{~F}$ value $=84.23$

Fig.1 Per hectare yield gap in sugarcane

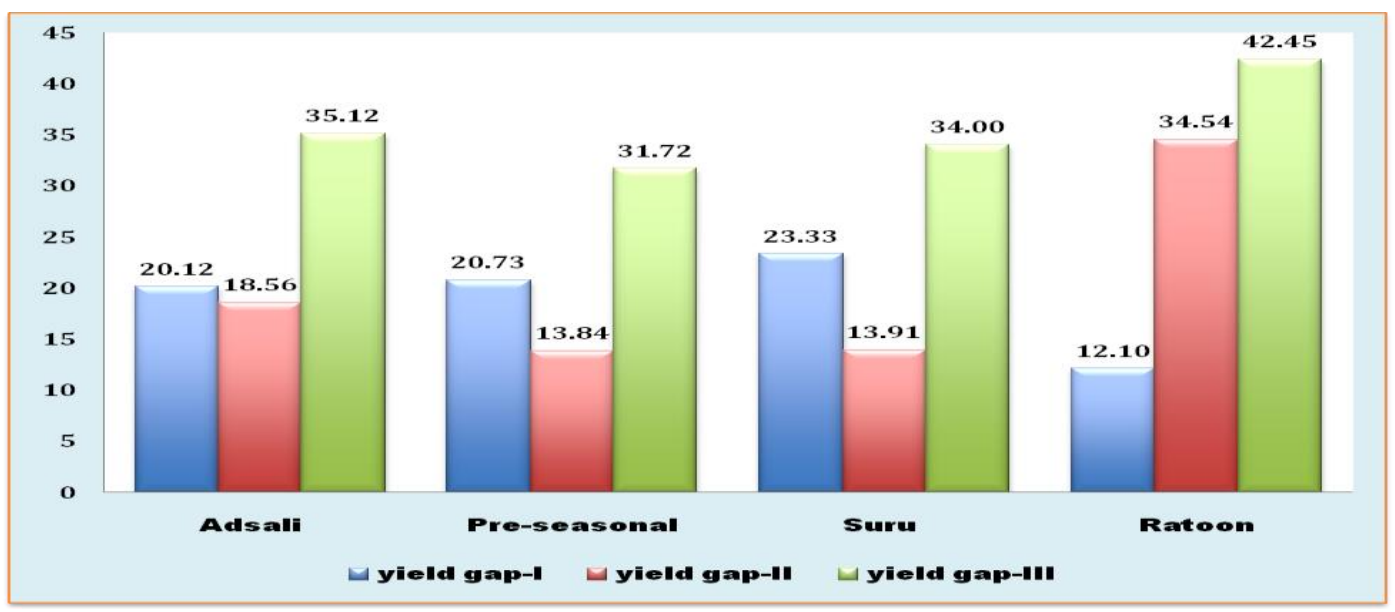

\section{Suru sugarcane}

Table 1 presents the average yield performance of suru sugarcane under different field situations. It is observed from table that, there existed a sizable gap in the suru sugarcane productivity between research station, demonstration plots and the sample farmer's fields. Suru sugarcane yield realised on the research station (150 tonnes per hectare) and on the demonstration plots (115 tonnes per hectare) were amply higher than on farmers' fields (90.00 tonnes per hectare). The total yield gap (yield gap III) was noticed to the extent of 40.00 per cent while, yield gap I and yield gap II were 23.33 per cent and 21.73 per cent, respectively. 


\section{Ratoon sugarcane}

The gap was noticed between productivity of research station, demonstration plots and sample farms of ratoon sugarcane. Ratoon sugarcane yield realised on the research station farms, demonstration plots and sample farms were 125 tonnes per hectare, 110 tonnes per hectares and 72 tonnes per hectares, respectively. It is inferred from table that, there was 12 per cent yield gap between potential yield and the potential farm yield. Yield gap II was 34. per cent and total yield gap (yield gap III) was 42.40 per cent at overall level.

\section{Factors affecting yield gap of sugarcane}

The coefficients of multiple determination $\left(\mathrm{R}^{2}\right)$ indicated the proportion of total variation in the dependent variable jointly explained by the independent variables. At the same time, regression coefficient of the individual resource variable (bi's) is the absolute change in the dependent variable in multiple regression equation. It indicated that one unit change in individual resource variable will bring the change in output by its respective regression coefficient. These results are of paramount importance as they provide readily information relating to probable effects of resource use changes on yield.

The table 2 shows the result of estimated regressions equation (multiple linear regression) fitted taking yield gap as dependent variable and several other critical input as independent variables. According to the table un standardized coefficients of number of set, expenditure on land preparation, manures, fertilizer, number of irrigation, total labour, machine power, age, experience, expenditure on plant protection and total value of assets are estimated 0.02, $0.02,0.026,0.210,0.92,0.07,0.16,0.21$, $0.19,0.002$, and 1.92 respectively. The number of irrigation, age, manure, experience, total value of assets where are non significant, while remaining are significant. The $\mathrm{R}^{2}$ value was found 0.86 , which show explanatory power of model, while the F-value was estimates 84.23 show the significance of overall independent variables in the model.

Before fitting the multiple linear regression equation, association of all inpertenal input were estimated with supervene output. This was done with the help of pearsions correlation analysis. The significance of correlation coefficient was tested with the help of " $t$ " test. Results reported in the table 2 reveled that, farm size, number of set, expenditure on land preparation, manures, fertilizer, total labour and machine power were significance. There inputs are found critical in supervene cultivation. Rest of the input does not have linear association with supervene yield. They are age, experience, plant protection etc.

The results of the estimated production function analysis indicated that the selected eleven independent variables have jointly explained 86 per cent variation in the yield gap of sugarcane. These significant coefficients indicated that one unit increase in the use of number of set (X1), expenditure on land prepration (X2), fertilizers (X4), total labour $\left(\mathrm{X}_{6}\right)$, and machine power $\left(\mathrm{X}_{7}\right)$ will minimize the gap in yield of sugarcane by the respective regression coefficients. manures $\left(\mathrm{X}_{3}\right)$, number of irrigations $\left(\mathrm{X}_{5}\right)$, age $(\mathrm{X} 8)$, experience (X9), expenditure on plant protection (X10), were non- significant (Table 3).

From the above discussion, it is apparent that, the over utilization of inputs such as Number of set, fertilizers, Total labour and Machine power were mainly responsible for the yield gap in the sugarcane plantations. These findings confirms with the results of Pokharkar (2000), priris (2009), Hangthong 
(2009) they also reported that, total labour, fertilizers, number of set, machine power are the important factors responsible for the yield gaps is accepted.

In conclusions the magnitude of yield gap-I at overall level, was higher for suru sugarcane $(23.33 \%)$ followed by pre-seasonal $(20.73 \%)$, adsali $(20.12 \%)$ and ratoon $(12.10 \%)$ which implies that, the technology developed at research station cannot be duplicated on demonstration plots to exploit the full potential of sugarcane. This gap was attributable to environmental differences and non transferable component of technology. The orthodox practices being followed on farmer's field lead to yield gap-II at overall level. Maximum yield gap-II was observed in ratoon sugarcane $(34.54 \%)$ because of poor management practices followed for ratoon sugarcane. The yield gap-II for adsali, suru and preseasonal sugarcane farms was 18.56 per cent, 13.84 per cent, 13.91 per cent, respectively. The farmers usually do not adopt a technology as a package but take up individual practices suitably trimmed to fit into their budget and skills (management and operational) which lead to the variation in the adoption of cultural practices and consequently to the yield gaps. The yield gaps cannot be completely eliminated, but can be minimized by efficient and effective resources management. Smaller the input gaps between the demonstration plots and the farmer's fields, larger the productivity gains on farmers' fields. It conclude that the over utilization of inputs such as Number of set, fertilizers, Total labour and Machine power were mainly responsible for the yield gap in the sugarcane plantations. These findings confirms with the results of Pokharkar (2000), priris (2009), Hangthong (2009) they also reported that, total labour, fertilizers, number of set, machine power are the important factors responsible for the yield gaps is accepted.

\section{References}

Deokate T. B, (2014) Quantification of yield gaps in different planting of sugarcane in western Maharashtra, Advance Research Journal of crop improvement, 5(1): 34-39.

Jadhav, M. S.; Pagires (2009) Yield gap analysis of adsali sugarcane in Sangli district of Western Maharashtra, Indian Sugar Mills Association, 58(10) 21-26.

Pushpa and S.K. Srivastava Yield gap analysis and the determinants of yield gap in major crops in eastern region of Uttar Pradesh, Economic Affairs, 59(4): 653-662.

Rao Rama I .V. Y (2012) Efficiency, Yield Gap and Constraints Analysis in Irrigated vis-a-vis Rainfed Sugarcane in North Coastal Zone of Andhra Pradesh, Agricultural Economics Research Review, 25(1) : 167-171.

\section{How to cite this article:}

Bodakhe, G. M., S. S. More and Dhokar, N. R. 2020. Yield Gap and Factor Influencing Yield Gap in Sugarcane Cultivation in Ahmednagar District of Maharashtra. Int.J.Curr.Microbiol.App.Sci. 9(12): 1664-1670. doi: https://doi.org/10.20546/ijcmas.2020.912.198 